\title{
Closing bodies in the capsular fruits of Ruschioideae (Aizoaceae)—a review
}

\author{
H. KURZWEIL* and P. BURGOYNE**:
}

Keywords: Aizoaceae, capsular fruits, closing bodies, hygrochasy, Mesembryanthema

ABSTRACT

\begin{abstract}
Capsular fruits of the Mesembryanthema* are uniquely diverse and have been used to establish groupings within the tribe Ruschieae. The function, structure and development of the closing bodies of the Ruschioideae are reviewed from existing literature and are supplemented by personal observations, providing a framework for future research aimed at resolving critical issues regarding the structure and taxonomic implications of the closing bodies of the Ruschioideae. The number of species per taxon, distribution and presence or absence of covering membranes and closing bodies within the Mesembryanthema are tabulated.
\end{abstract}

\section{INTRODUCTION}

In the past, the structure of the capsular fruits was considered critical in the systematics of the Mesembryanthema (Herre 1971; Hartmann 1988, 1991, 1993, 2001; Smith et al. 1998). In particular, it is the internal structure of the capsular fruits that yields most of the variable characters. However, with the publication of molecular data by Klak et al. $(2003,2007)$ it was found that the groupings proposed by Hartmann were not supported by molecular data.

In many Mesembryanthema the locules are covered by roof-like lids known as covering membranes, leaving only a narrow distal opening through which seeds can be dispersed. This entrance is frequently closed to some degree and the blockage has an immensely important role in the dissemination biology of the Mesembryanthema as it results in the complete or partial occlusion of the locule. Seeds are consequently locked in and cannot simply be washed out by raindrops as in other species that lack such blocking devices. This structure results in the seeds being forced out, jet-like, through the gaps between the covering membranes (Parolin 2006).

The distal closing devices are generally very diverse in their structure, but two main types are distinguished. By far the most striking are the closing bodies, which are prominent and often hemispherical structures formed on the fruit wall near the upper end of the placentas (Figure 1A). The second type of closing device (Figure 1B), in the form of bulges, ledges and rodlets (Hartmann 1991), occurs on the lower surface of the covering membrane near the distal end. In a number of species, none of these closing devices are present, but dense bundles of funi-

\footnotetext{
- National Parks Board, Singapore Botanic Gardens, 1 Cluny Road. Singapore 259569; e-mail: Hubert_KURZWEIL@ nparks.gov.sg.

** National Herbarium, South African National Biodiversity Institute, 0001 Pretoria; e-mail: Burgoyne@ sanbi.org.

$\ddagger$ Research Fellow, Department of Environmental Sciences, University of South Africa, P.O. Box 392, 0003 UNISA Pretoria.

MS. received: $2007-04-20$,
}

\footnotetext{
- The subfamilies Mesembryanthemoideae and Ruschioideae together are termed Mesembryanthema (Hartmann 1991) and represent a group without taxonomic rank.
}

cles sometimes close the locule entrance to a certain extent (Figure 1C; Lampranthus Group, Hartmann 1988, 1991; some Drosanthemum species, Hartmann \& Bruckmann 2000; Hereroa, Dehn 1992). In some Mesembryanthema, the free upper ends of the placentas contribute to the occlusion of the locules (Dehn 1992).

In this paper we are dealing only with the first type. Closing bodies are normally easily visible with the naked eye, particularly the larger ones, which can be up to 2 $\mathrm{mm}$ in diameter. In an open capsule they are very conspicuous as they are mostly pale and often have a shiny surface, thus contrasting with the dark brown remainder of the capsule. Owing to their prominent appearance, these bodies were already discovered in the early days of botanical exploration of the arid regions of southern Africa. The generic name of the genus Disphyma N.E.Br. is derived from the closing bodies (two-lobed in this case).

Much has been said about the function, structure and development of the closing bodies of the Ruschioideae (Berger 1908; Huber 1924; Lockyer 1932; Schwantes 1952, 1957; Volk 1960; Ihlenfeldt 1960, 1971; Haas 1976; Hartmann 1988, 1991, 1993; Hartmann \& Gölling 1993; Kurzweil 2005). Comments on the closing bodies of individual species are also found in numerous floristic and taxonomic publications, but most of these are merely descriptions of their shape, size and colour. Detailed investigations and comparisons of these prominent capsule features are rare in literature (Poppendieck 1976; Hartmann 1988), and a number of problems exist, calling for further studies. While the overall appearance of the closing bodies was often used as a diagnostic feature of certain genera and species, there is as yet no clear and well-documented comparative survey of these bodies. Furthermore, information on fruit characters in general is scattered throughout the taxonomic literature and is often not easily accessible (language barrier, some journals not easily obtainable). The present paper aims to review the existing literature on the closing bodies of Mesembryanthema and is supplemented by personal observation. It is hoped that this review will provide the starting point for future research aimed at resolving critical issues regarding the structure and taxonomic implications of the closing bodies of the Ruschioideae. 


\section{THE CLOSING BODIES AND THEIR STRUCTURE}

Closing bodies are mostly round and often hemispherical protrusions positioned on the fruit wall below the distal ends of the covering membranes at the upper end of the placentas (Figure 1A). Their size ranges from less than $1 \mathrm{~mm}$ to $2 \mathrm{~mm}$ in diameter. The closing bodies are
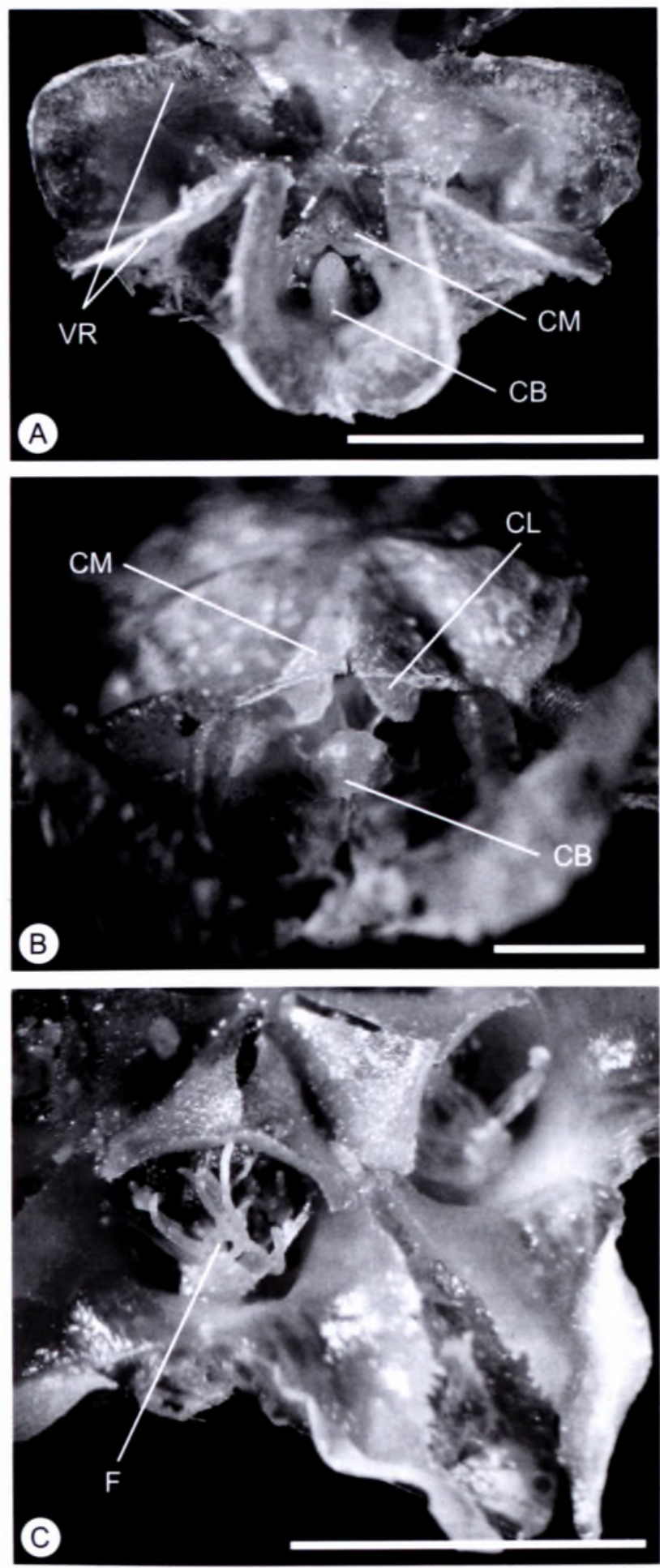

FIGURE 1.-A, Ruschia lineolata, Burgoyne 9848: closing bodies formed on fruit wall near upper end of placentas; B, Ruschia sp. Burgoyne 8102; closing ledges formed on lower surface of distal end of covering membranes; C, Lampranthus watermeyeri, Burgoyne 7562 or Smicrostigma viride, Steyn 384: dense bundles of funicles close locules. CB, closing bodies; CL, closing ledges; $\mathrm{CM}$, covering membranes; F, funicles: VR, valve rims. Scale bars: A. $4 \mathrm{~mm}$ or $3 \mathrm{~mm}$; B. C. $5 \mathrm{~mm}$. firmly united with the placentas, the upper ends of the latter often running in a pronounced groove. The larger closing bodies often touch the covering membranes and thus close the locule completely, and in many cases also reach partly under the latter. Small or tiny closing bodies are sometimes rather deeply positioned inside the locule (for example in some genera of the Eberlanzia Group). Prominent closing bodies have only been reported in subfamily Ruschioideae, and then only in genera that have complete or nearly complete covering membranes in their capsular fruit (although closing bodies do not occur in all of the genera with covering membranes).

The term 'closing bodies' was originally coined by Steinbrinck (1883). Later Huber (1924) considered these structures as formations of the placentas and consequently termed them 'Plazentarhöcker' (= placental tubercles). This term was subsequently adopted by many textbooks and taxonomic treatments. Ihlenfeldt (1960) on the other hand, interpreted these formations as a product of the endocarp and suggested reverting to the original term 'closing bodies'. After a detailed examination of the closing bodies of Pleiospilos N.E.Br., Hartmann \& Liede (1986: 458) also rejected Huber's controversial term 'tubercle' as completely inadequate.

The shape of the closing bodies of the Ruschioideae is very diverse. Particularly elaborate closing bodies are found in Hartmann's (1993) Leipoldtia Group. They are normally rather large and consist of a 'head' borne on a distinct stalk. Anatomically, the central part is made up of large, spongy cells covered by several cell layers of sclerenchymatic tissue. Smaller rodlet-shaped closing bodies are found in the Ruschia type of fruit (Hartmann 1988 ) and have a similar anatomy. Comparatively small, hook-shaped closing bodies are found in the Titanopsis type of fruit, and they consist of sclerenchymatic cells only (Hartmann 1988: 327). The closing bodies of the Mitrophyllum type of fruit are not prominent hemispherical bodies, but appear as broad ridges or bosses where the placentas and expanding keels meet (Poppendieck 1976; Ihlenfeldt \& Struck 1987). Their epidermis is only moderately thick-walled and an extensive spongy tissue is present. In some genera referred to this fruit type. broad, spongy closing bodies have the shape of ledges and have also been termed as such (Hartmann 1991): the closing ledge of Dorotheanthus Schwantes has been referred to as 'Verschlusswall' (= closing sill) (Ihlenfeldt \& Struck 1987). Hartmann (1988) suggested that these aforementioned types of closing bodies are not all homologous

According to their ontogenetic derivation, most of the closing bodies of the Ruschioideae are endocarpal structures. A few other species possess small placental closing bodies, which have a different texture and anatomy (Hartmann 1988). This emerged originally from a careful study of the closing bodies of Pleios pilos (Hartmann \& Liede 1986) where the following were observed: 1 , endocarpal closing bodies are often large, although small and insignificant endocarpal bodies have also been reported occasionally, e.g. Tanquand H.E.K.Hartmann \& Liede (1986). Endocarpal closing bodies comprise an epidermis of sclerenchymatic cells over a body of isodiametric cells with equally thick walls, the central part of the closing body comprising 
either parenchymatic or sclerenchymatic cells. Thus they differ markedly from the cells of the placentas which have unthickened walls throughout. The derivation of these prominent closing bodies from endocarpal tissue has also been found by Kurzweil (2005); 2, placental closing bodies are rare in the Mesembryanthema and contribute only a little to the occlusion of the locule. Examples include Malephora N.E.Br., Pleiospilos nelii Schwantes, P. simulans (Marloth) N.E.Br. and P. bolusii (Hook.f.) N.E.Br. (Hartmann \& Liede 1986). They are made up of cells with only weakly thickened or unthickened walls, although the cell walls of the epidermis can be strongly thickened. In Drosanthemum Schwantes, the endocarp may form a little protrusion, lifting the closing body slightly (Hartmann \& Bruckmann 2000: 81).

The genera Disphyma and Rhombophyllum (Schwantes) Schwantes have two-lobed closing bodies. The situation in a few other genera is somewhat reminiscent of this condition as the closing bodies and their stalks have a more or less deep groove (although this is often largely obscured by the placentas). It is suggested that this partial or complete two-lobed condition is a reflection of the origin from two carpel margins (Kurzweil 2005).

While in most genera the closing bodies are constant in their size and can therefore be used as diagnostic characters, some intraspecific variation was found in Mitrophyllum Schwantes (Poppendieck 1976), Dorotheanthus subgen. Dorotheanthus (Ihlenfeldt \& Struck 1987) and Disphyma (Chinnock 1996). The shape of the closing bodies of Odontophorus marlothii N.E.Br. varies even within the same capsule (Hartmann 1976).

\section{DISTRIBUTION OF CLOSING BODIES IN THE RUSCHIOIDEAE}

Only the subgroups of subfamily Ruschioideae are treated here, as closing bodies do not occur in subfamily Mesembryanthemoideae (Figure 2A). The following is a brief review of detailed investigations of the closing bodies of individual genera in the literature. Comparative descriptions and discussions of these structures can also be found in Hartmann (1983, 1988) and Dehn (1992). Overall descriptions of shape, size, colour and consistency of closing bodies are found throughout taxonomic and floristic literature and are not listed here.

The arrangement of the subfamilies and tribes follows the classification of Klak et al. (2003). The large subfamily Ruschioideae is divided in four groups (clades), two of these representing the tribes Apatesieae and Dorotheantheae (corresponding to the Apatesia and Cleretum Groups of Hartmann 1993). They form a monophyletic, well-supported group, supported by molecular data (Klak et al. 2003). The remaining two clades fall within the tribe Ruschieae in which few DNA sequence changes have been observed (Klak et al. 2003). Hartmann (1988) has proposed 10 groups for the species in the tribe Ruschiae. Table 1 gives a short summary of the number of species per taxon, distribution and presence or absence of covering membranes and closing bodies within the Mesembryanthema
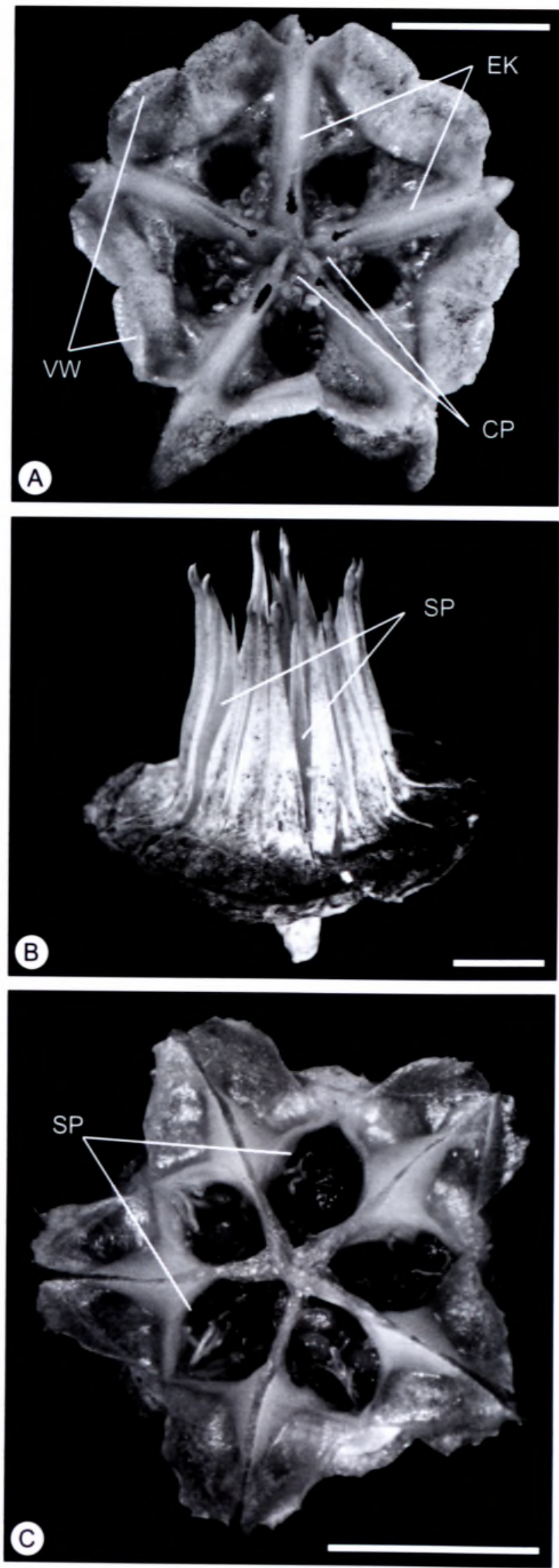

FIGURE 2.-Fruit types. Mesembryanthemoideae: A, Mesembryanthemum hypertrophicum, Bungoyne 10349. Tribe Apatesieae: B, Conicosia pugioniformis (L.) N.E.Br. subsp. alborosea (L.Bolus) Ihlenf. \& Gerbaulet, Burgoyne 10378. Tribe Dorotheantheae: C, Cleretum papulosum (L.f.) L.Bolus subsp. papulosum, Burgoyne $9396(b)$, showing prominent seed pockets. CP, central placentation; EK, expanding keels (parallel); SP, seed pockets; VW, valve wings. Scale bars: A, $6 \mathrm{~mm}$; B, $10 \mathrm{~mm}$; C, $4 \mathrm{~mm}$. 


\section{Tribe Apatesieae Ihlenf., Schwantes \& Straka}

This tribe corresponds to the Apatesia Group of Hartmann (1993). Fruit capsules are characterized by the reduction of hygrochasy, absence of valve wings and frequent seed retention in seed pockets (Figure 2B, Apatesia type of fruit; Hartmann 1988). The capsules are sometimes schizocarps that break up into mericarps (especially prominent in the genus Caryotophora Leistner), which are then dispersed as a whole. Covering membranes as well as closing bodies are absent.

Tribe Dorotheantheae (Schwantes ex Ihlenf. \& Struck) Chess., Gideon F.Sm. \& A.E.van Wyk

The species of this group (corresponding to the Cleretum Group of Hartmann 1993) have capsules with or without covering membranes and prominent expanding sheets (Figure 2C). Sometimes they have comparatively insignificant closing bodies (Hartmann 1988, 1991), developed as swellings, spongy sills or ridges but not as large, hemispherical structures as in other Mesembryanthema genera. These closing bodies have a broad base, which is typical of the Mitrophyllum type of fruit to which the Dorotheantheae are referred (Hartmann 1988). Ihlenfeldt (1960) and Ihlenfeldt \& Struck (1987) also described these ridge-like closing bodies (referred to as 'Verschlusswall' = closing sill), which are found in some species of the genus Dorotheanthus. They are best developed in D. bellidiformis (Burman) N.E.Br. subsp. bellidiformis. Generally, the ridge-like closing bodies of this group are interpreted as a product of the endocarp and not the placenta (Ihlenfeldt 1960: 49). In the genus Dorotheanthus, the occurrence of the seven different capsule types defined on the basis of features of the covering membranes and closing bodies is geographically correlated, and species with capsules that have pronounced closing bodies are more frequent in the southern parts of the distribution area (Ihlenfeldt \& Struck 1987).

\section{Tribe Ruschiae Ihlenf., Schwantes \& Straka}

This group comprises most of the Ruschioideae, currently including nearly 1600 species. An enormous diversity in the capsular fruit structure is found in this group.

\section{Mitrophyllum Group}

The capsules have mostly been referred to the Mitrophyllum type of fruit (Figure 3A; Hartmann 1988). Covering membranes are mostly complete but are sometimes reduced, and the surface of expanding keels are extended to form flat expanding sheets. Closing bodies are sometimes present, and are mostly developed as spongy sills or ridges and have a broad base. They are rather variable in the extent of their formation but are rarely very large (Glottiphyllum (Haw.) N.E.Br.). Valve wings are mostly broad, though sometimes very narrow or absent.

In Disphyma the closing bodies are deeply two-lobed (Chinnock 1996). However, in D. papillatum Chinnock the closing bodies are variable in size and range from well developed to vestigial, and $D$. australe (Aiton) J.M.Black lacks closing bodies altogether. An abnormal population of this species with variously shaped finger-like outgrowths at the entrance of the locules was reported by Chinnock (1996). Glottiphyllum has large

TABLE 1.-Distribution of closing bodies in the Mesembryanthemaceae. Subfamilies and tribes after Klak et al. (2003), informal groups after Hartmann (1991, 1993, 1998a). Approximate numbers of species follow Hartmann (1993) and Klak et al. (2003, 2007)

\begin{tabular}{|c|c|c|c|c|}
\hline Taxon & $\begin{array}{l}\text { No. } \\
\text { species }\end{array}$ & Distribution & $\begin{array}{l}\text { Covering } \\
\text { membranes }\end{array}$ & Closing bodies \\
\hline Subfamily Mesembryanthemoideae & \pm 102 & $\begin{array}{l}\text { Widespread in South Africa and Namibia; Mesem- } \\
\text { bryanthemum also in coastal areas worldwide }\end{array}$ & Absent & Absent \\
\hline \multicolumn{5}{|l|}{ Subfamily Ruschioideae } \\
\hline Tribe Apatesieae & 11 & $\begin{array}{l}\text { Mainly western parts of South Africa, with Conico- } \\
\text { sia ranging into southern Namibia }\end{array}$ & Absent & Absent \\
\hline Tribe Dorotheantheae & 11 & Western parts of South Africa & Present or absent & $\begin{array}{l}\text { Present as a ledge or } \\
\text { absent }\end{array}$ \\
\hline \multicolumn{5}{|l|}{ Tribe Ruschiae } \\
\hline Mitrophyllum Group & 51 & $\begin{array}{l}\text { Widespread in South Africa, with Disphyma rang- } \\
\text { ing into Australia and New Zealand }\end{array}$ & Present or absent & $\begin{array}{l}\text { Present (broad-based) } \\
\text { or absent }\end{array}$ \\
\hline Delosperma Group & 325 & $\begin{array}{l}\text { Widespread in southern Africa, with Delosperma } \\
\text { ranging into eastern Africa and Yemen }\end{array}$ & Present or absent & Very rarely present \\
\hline Stomatium Group & 102 & South Africa and southern Namibia & Present or absent & Mostly absent \\
\hline Titanopsis Group & 79 & Widespread in South Africa and Namibia & Present or absent & Very rarely present \\
\hline Dracophilus Group & 122 & Widespread in South Africa and southern Namibia & Mostly reduced & Absent \\
\hline Bergeranthus Group & 54 & $\begin{array}{l}\text { Widespread in South Africa and southern half of } \\
\text { Namibia }\end{array}$ & Mostly complete & $\begin{array}{l}\text { Mostly present, but } \\
\text { often small }\end{array}$ \\
\hline Lampranthus Group & 248 & $\begin{array}{l}\text { Widespread in South Africa and southern Namibia, } \\
\text { with Carpobrotus extending to coastal areas } \\
\text { worldwide }\end{array}$ & Complete & Almost always absent \\
\hline Ruschia Group & 375 & Widespread in South Africa and Namibia & $\begin{array}{l}\text { Complete, often } \\
\text { convex }\end{array}$ & $\begin{array}{l}\text { Small to medium- } \\
\text { sized, often hook- } \\
\text { shaped }\end{array}$ \\
\hline Leipoldtia Group & 163 & Widespread in South Africa and southern Namibia & $\begin{array}{l}\text { Complete, often } \\
\text { concave }\end{array}$ & $\begin{array}{l}\text { Large and stalked, } \\
\text { rarely small }\end{array}$ \\
\hline Eberlanzia Group & 17 & $\begin{array}{l}\text { Western parts of South Africa, southwestern } \\
\text { Namibia }\end{array}$ & Complete & $\begin{array}{l}\text { Large or small, some- } \\
\text { times deep in locule }\end{array}$ \\
\hline
\end{tabular}


A
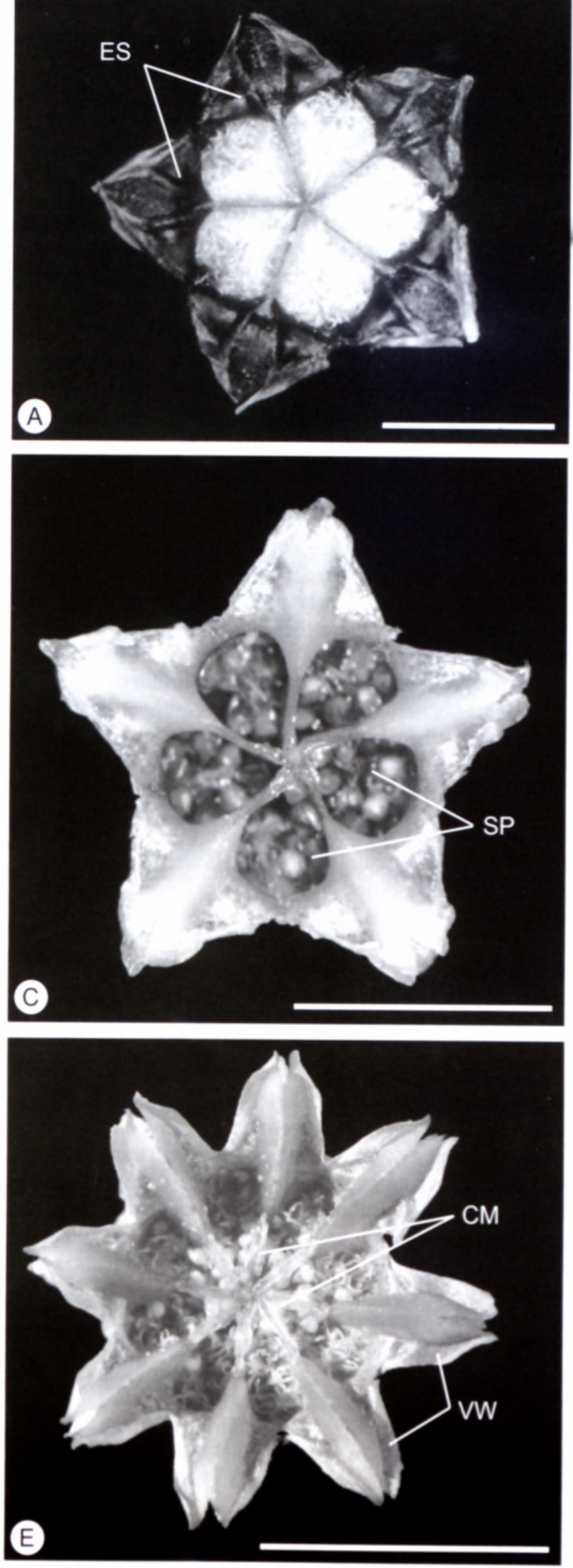
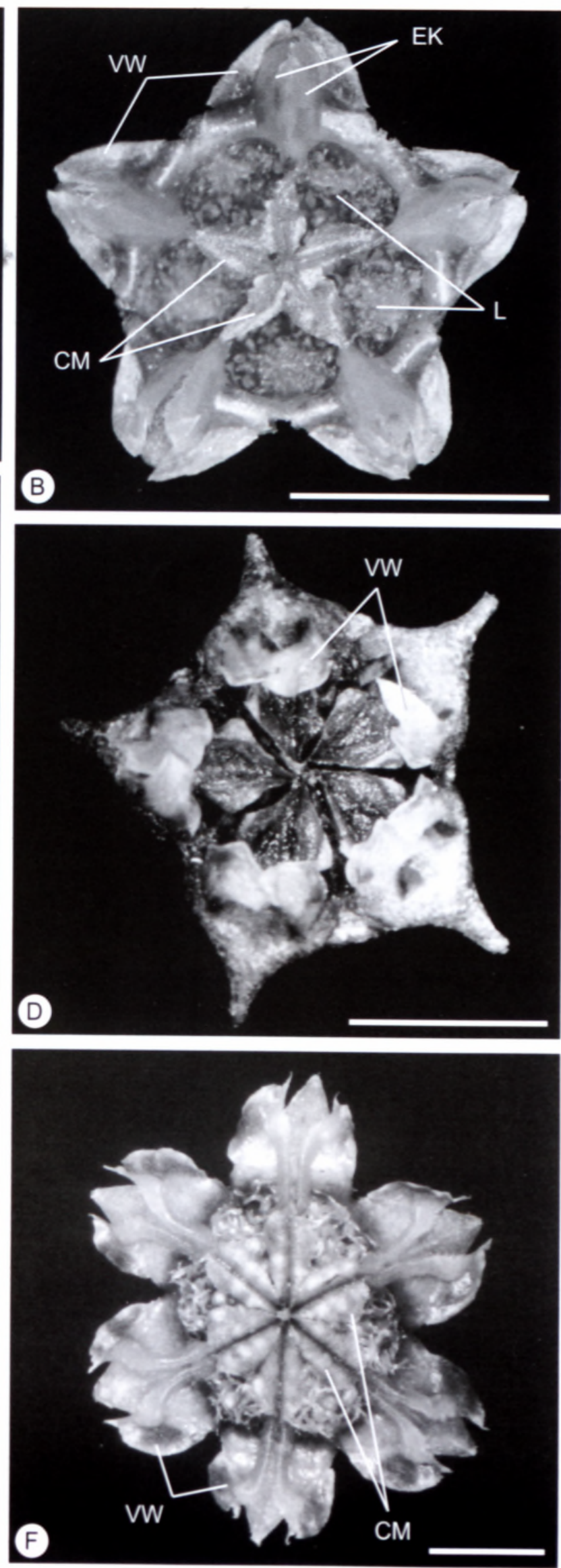

FIGURE 3.-Fruit types. Mitrophyllum type: A, Monilaria chrysoleuca, Burgoyne 9454B. Delosperma type: B, Delosperma floribundum, Muller 1776. Stomatium type: C. Stomatium sp., Burgoyne 8966. Faucaria type: D, Faucaria sp., Van Jaarsveld III04, with prominent valve wings borne erect. Dracophilus type: E, Juttadinteria deserticola (Marloth) Schwantes, Burgoyne 8453B. Titanopsis type: F, Titanopsis calcarea (Marloth) Schwantes, Burgoyne 9619. CM, covering membranes (reduced); ES, expanding sheets; EK, expanding keels; L. locules; SP, seed pockets; VW, valve wings. Scale bars: A, B, $6 \mathrm{~mm}$; C, $5 \mathrm{~mm}$; D. $4 \mathrm{~mm}$; E. $9 \mathrm{~mm}$; F, $3 \mathrm{~mm}$. 
spongy closing bodies with a broad base; their endocarpal origin has been shown by Hartmann \& Liede (1986). Hartmann's (1991) concept to include Glottiphyllum in the Mitrophyllum Group is also supported by features of the expanding tissue (Hartmann \& Gölling 1993). Earlier, an alternative concept was proposed by Schwantes (1952) listing this genus under his Glottiphyllum type of fruit, together with the genera Cheiridopsis N.E.Br., Pleiospilos and Argyroderma N.E.Br. In G. difforme (L.) N.E.Br., G. fergusoniae L.Bolus, $G$. nelii N.E.Br. and $G$. oligocarpum L.Bolus, the closing bodies are over-arched by a tongue- or triangle-like tissue of the outer locule wall (Hartmann \& Gölling 1993). The closing bodies of various species in the genus Mitrophyllum are variable in the extent of their formation even within the same population (Poppendieck 1976). They are generally apparent as swellings or swollen ridges in a position where the placentas and the expanding sheets meet. Anatomically, they are made up of isodiametric cells with strongly thickened walls. The epidermis in their proximal part consists of similar cells but the cells in the distal part are elongate (when seen in a longitudinal section) and have weakly thickened walls, thus resembling the cells of the adjacent expanding tissue.

\section{Delosperma Group}

The capsules of this group (Figure 3B) are rather diverse, and the different genera were referred to the Delosperma N.E.Br., Drosanthemum and Lampranthus N.E.Br. types of fruit (Hartmann 1988). Seed pockets occur occasionally. Expanding keels are usually distinct from the expanding sheets and the valves have mostly broad wings. Covering membranes are present or absent. Closing bodies are almost always absent, but the genus Malephora often has knobs on the distal end of the placentas which act as closing bodies (Hartmann 1988: 56 ); these placental closing bodies may also be bilobed. Small and often bilobed endocarpal closing bodies are found in some species of the genus Drosanthemum, and most species of this genus have placental closing bodies (Hartmann \& Bruckmann 2000).

\section{Stomatium Group}

The capsules can mostly be referred to the Delosperma and Drosanthemum types of fruit of Hartmann (1988). Covering membranes are present or absent, and valve wings are broad to reduced or absent. Seed pockets derived from basal false septa are found in Stomatium Schwantes (Figure 3C). Closing bodies are normally absent in the group but small, obscure ones are found in Orthopterum L.Bolus.

Herre (1971) stated that distinct bifid closing bodies were also found in Chasmatophyllum maninum L.Bolus, whereas they were absent in the rest of this genus. We examined the notes accompanying the protologue made by Bolus (1927), where she stated that capsules of $C$. manimum were not yet available and a drawing of the portion of a capsule of $C$. musculinum (Haw.) Dinter \& Schwantes was given, showing bifid closing bodies. Both Bolus and Herre made an error in citing bifid closing bodies for Chasmatophyllum maninum. Examination by the authors of many recently collected specimens of C. musculinum has shown no bifid closing bodies.
Hartmann (1988) placed Faucaria Schwantes and Orthopterum in this group, but for an alternative view, which is followed below, see Groen \& Van der Maesen (1999).

\section{Faucaria Group}

This group corresponds to the section established by Schwantes (1952) and reinstated by Groen \& Van der Maesen (1999) and comprises only two genera (Faucaria and Orthopterum) as their capsules are unique (Figure 3D). When the capsules are viewed after wetting, one gets the impression that they are empty, as locules are hidden by lamellae curving over the top of the locules. The capsules are 5(6)-locular and are deep, the valves with fissures between them. Conventional covering membranes and closing bodies are absent and expanding keels end in an awn. The deep locules combined with curved lamellae are highly effective in retaining seeds during periods of low rainfall. Capsules can become detached after ripening by being pushed out by the enlarging leaf pair produced the following season and may roll away, but are never found more than a few centimetres from the parent plants (Groen \& Van der Maesen 1999). Particularly prominent valve wings are found in Faucaria where they are borne erect when the capsule is open. When dry, these valve wings fold back into thin grooves. Orthopterum has similar fruits with their septa separated into two parts, the upper part arching on top of the capsule.

\section{Titanopsis Group}

The capsules of this group (Figure 3F), mostly referred to Hartmann's (1988) Titanopsis Schwantes and Delosperma types, have well-developed or reduced covering membranes and broad valve wings which taper distally. Closing bodies are mostly absent, although they are developed as tiny (rarely prominent) structures in some species of Aloinopsis Schwantes, Tanquana and Ihlenfeldtia H.E.K.Hartmann.

The genus Ihlenfeldtia was established to include two species previously included in Cheiridopsis (Hartmann 1992). This genus is characterized by its distinct fruit morphology, with mostly 10 locules, thin, straight, complete covering membranes, and valve wings that are broad at the base. Endocarpal closing bodies are present and are illustrated by line drawings in Hartmann's publication. Anatomically, they comprise a translucent layer of vertical cells on top of a sclerenchymatic body. The small genus Tanquana was separated from Pleiospilos as it differs in several characters including its fruit structure (Hartmann \& Liede 1986). Capsules were shown to be generally less robust than those of Pleiospilos, having thinner valves and covering membranes. Important distinguishing features were found in the structure of the closing bodies, which are small and of endocarpal origin.

\section{Dracophilus Group}

Fruits of this group (Figure 3E) mostly belong to the Delosperma type of capsule (Hartmann 1988). Covering membranes are mostly reduced to form a narrow rim, and valve wings are usually prominent. Closing bodies are generally absent. 


\section{Bergeranthus Group}

This group has fruits that are close to the Mitrophyllum type of Hartmann (1988) but generally have stout and firm covering membranes (Figure 4A). The valve wings are mostly reduced to narrow organs and are often awn-like; occasionally they are absent altogether. Closing bodies are present or absent.

The spongy closing bodies of Bergeranthus Schwantes are rather large plates (Schwantes 1952: 16; Hartmann 1993: 61). In Cerochlamys N.E.Br., the small closing bodies are of placental origin and they are frequently overarched by a translucent layer of tissue that is derived from the expanding sheets (Hartmann 1998b: 52). The placental closing bodies of Hereroa (Schwantes) Dinter \& Schwantes are tiny (Hartmann 1993: 61). In this genus the locule entrance is often closed by long funicles (Dehn 1992: 135). Small and frequently deeply set closing bodies are found in Machairophyllum Schwantes where they may be irregular in shape (Kurzweil \& Chesselet 2003). Rhombophyllum species have large, flat or rounded and bipartite closing bodies (Schwantes 1952: 15-17; Hartmann 1993: 61).

\section{Lampranthus Group}

Most genera of this group have capsules of the Lampranthus type (Figure 4B; Hartmann 1988). While hygrochastic capsules are the norm, Carpobrotus N.E.Br. species differ by being the only genus within the tribe Ruschieae to have indehiscent fleshy berries (Figure $5 \mathrm{~A}$ ). Locules have rigid covering membranes with additional closing devices at the distal end. Together with sterile funicles, these closing devices on the underside of the covering membranes are largely responsible for closing the entrance to the locule. Valve wings are present or absent. Prominent closing bodies have only been reported in the genus Enarganthe N.E.Br. (Herre 1971) but are absent in all other genera.

\section{Ruschia Group}

This is a large group with fruits mostly of the Ruschia type (Figure 4C; Hartmann 1988). Fruits normally remain on the plants (occasionally up to several years) and release the seeds after dehiscence, but tumble fruits are found in Khadia N.E.Br. and rarely also in Ruschia Schwantes. The frequently deep locules have firm, complete covering membranes with additional closing devices at the distal end. Expanding keels are often widely diverging and valve wings are mostly absent or reduced. Closing bodies are small or medium-sized and hook- or rodlet-shaped. They are comparatively large in Acrodon N.E.Br. (Burgoyne 1998), a genus with a capsule structure that is somewhat reminiscent of the Leipoldtia type of fruit according to Hartmann (1988).

An endocarpal closing body that is largely covered by the placenta was reported in Ebracteola montis-moltkei (Dinter) Dinter \& Schwantes (Hartmann 1996: 39). Closing bodies of Khadia are of complex composition (Chesselet \& Hartmann 1995; Chesselet et al. 1998), and the various types can be used to identify the different species of the genus: the 'closing bodies' are either prominent placental formations or endocarpal protrusions and
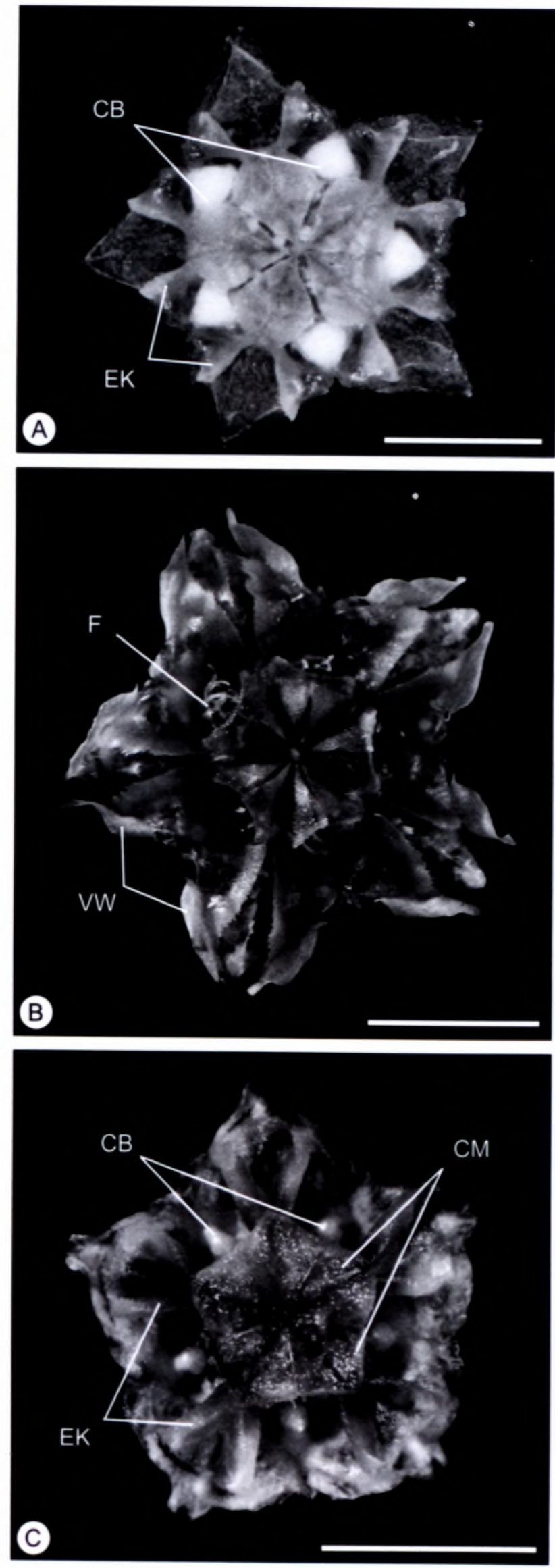

FIGURE 4.-Fruit types. Bengeranthus type: A, Bengeranthus multiceps (Salm-Dyck) Schwantes, Burgoyne 8918. Lampranthus type: B, Lampranthus watermeyeri, Bungoyne 7562. Ruschia type: C, Ruschia maxima (Haw.) L.Bolus, Bungoyne 8767. CB, closing bodies; CM, covering membranes; EK, expanding keels; F, funicles; VW, valve wings. Scale bars: A, $4 \mathrm{~mm}$; B, $7 \mathrm{~mm}$; C, $5 \mathrm{~mm}$. 

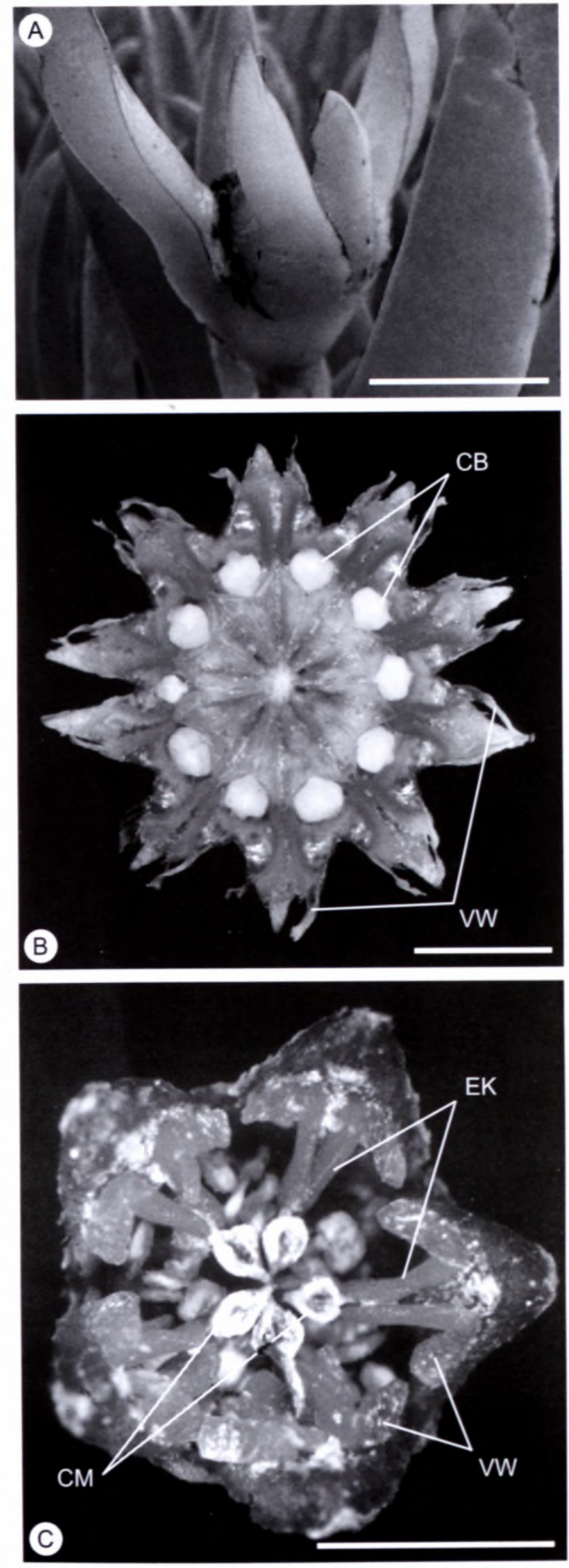

FIGURE 5.-Fruit types. Fleshy in A, Carpobrotus edulis (L.) L.Bolus subsp. edulis, Burgoyne 6317. Leipoldtia type: B, Cheiridopsis namaquensis (Sond.) H.E.K.Hartmann, Burgoyne 9487. Eberlanzia type: C, Stoeberia frutescens (L.Bolus) Van Jaarsv., Burgoyne 10323. $\mathrm{CB}$, closing bodies; $\mathrm{CM}$, covering membranes: EK, expanding keels; VW, valve wings. Scale bars: A, $25 \mathrm{~mm}$; B, $5 \mathrm{~mm}$; C, $4 \mathrm{~mm}$. are partly covered by some outgrowth of the expanding sheets. Dehn (1992) showed that the endocarpal closing bodies of Ruschia are comprised mainly of irregular, thin-walled cells, and are covered by 3-6 layers of prosenchymatic and moderately thick-walled cells plus a one-layered sclerenchymatic epidermis, which corresponds well with the observations of Hartmann \& Liede (1986). Based on structure, six types of closing bodies were distinguished by Hartmann \& Liede (1986) in the study of Ruschia and related genera.

\section{Leipoldtia Group}

Most genera of this group were referred to the Leipoldtia type of fruit (Figure 5B; Hartmann 1988), characterized by: 1 , persistent, \pm concave, complete covering membranes that frequently have additional closing devices in the form of bosses or ledges; 2, mostly large and distinctly stalked closing bodies; 3 , broad (rarely reduced) valve wings.

Capsules normally remain on the plant but tumble fruits are known in Fenestraria N.E.Br. and Cephalophyllum N.E.Br. This is the only group of Mesembryanthema in which the closing bodies are consistently present as prominent structures. They are also large in most genera-comparatively small closing bodies are found only in Fenestraria (Hartmann 1982), Jordaaniella H.E.K. Hartmann (Hartmann 1984) and Cylindrophyllum Schwantes (Herre 1971). Their surface is often rugose (Hartmann 1991: 124). The texture of the closing bodies of this group is corky, with sclerenchymatic outer layers. Most genera of this group have been taxonomically revised by H.E.K. Hartmann (several papers, see below; sometimes with co-workers), with detailed comments on many plant features including the closing bodies.

As part of a detailed study of the genus Antimima N.E.Br. emend Dehn, Dehn (1988) described the closing bodies and illustrated them by means of line drawings and SEM micrographs. The large closing bodies are shortstalked and of endocarpal origin. Hartmann (1977) revised the genus Argyroderma and examined the late development of the closing bodies of $A$. congregatum L.Bolus. It was shown that the cells of the closing bodies still have unthickened walls at the time of anthesis and become thickened only later. The structure and position of the closing bodies of the genus Cephalophyllum was described by Hartmann (1978). According to Hartmann \& Dehn (1987), species of Cheiridopsis have large closing bodies in the mature fruits, which often partly reach under the distal parts of the covering membranes and close their entrance entirely. No taxonomic correlation of the different types of closing bodies was found. An informative SEM micrograph of the stalked closing body of Leipoldtia schultzei (Schlechter \& Diels) Friedrich was shown by Hartmann \& Rust (1994). The shape and surface of the closing bodies of Odontophorus marlothii was found to be variable within one population and even within the same capsule, and can therefore not be used as a diagnostic feature (Hartmann 1976). The genus Pleiospilos was examined in detail by Hartmann \& Liede (1986). It was shown that the five species of $P$. subgenus Punctillaria have large endocarpal closing bodies that close the locule entrance almost completely and are entirely made up of sclerenchymatic cells. The epidermis cells are elongate (vertically arranged), whereas the cells of subja- 
cent layers are isodiametric. The three species of $P$. subgenus Pleiospilos have small placental closing bodies comprising isodiametric cells with unthickened walls although their epidermis cells can have slightly thickened walls.

In our opinion, Antimima and Cylindrophyllum do not belong in the Leipoldtia Group. Antimima is better placed within the Ruschia Group and Cylindrophyllum belongs in the Bergeranthus Group.

\section{Eberlanzia Group}

This small informal group was established by Hartmann (1998a). In Eberlanzia Schwantes (Figure 5C) and Amphibolia L.Bolus, the fruit structure is similar to that of Ruschia except for the broad valve wings. Closing bodies in the group are small or large, sometimes deeply set in the locule. Fruits breaking up into nutlets are found in Stoeberia Dinter \& Schwantes where the anemochoric seeds are also unusual. SEM illustrations of closing bodies of Amphibolia laevis (Aiton) H.E.K.Hartmann were shown by Hartmann \& Dehn (1989).

\section{FUNCTIONAL ASPECTS}

Seed dispersal in the Mesembryanthemaceae is defined as ombrohydrochorous, i.e. triggered by rain drops. The covering membranes, which prevent the simple washing-out of the seeds, always comprise two parts that are arranged roof-like but are never fused on top. It has been shown that the association of flexible covering membranes and prominent closing bodies results in an increased water pressure in the locule after a direct hit by a rain drop (Parolin 2006), and consequently the seeds are expelled jet-like, following a bending of the covering membranes (Berger 1908; Lockyer 1932; Schwantes 1952). Lockyer (1932) showed that this complete occlusion of the locule actually promoted dissemination in space, as jet-like expelled seeds fell further from the parent plant than merely washed-out seeds would. The same mechanism also protracts dispersal in time, i.e. results in slow or delayed release of the seeds (Ihlenfeldt 1971), and this is obviously ecologically advantageous in the arid habitat of the Mesembryanthemaceae. The role of the small closing bodies of some species that close the distal entrance of the covering membranes only partly is not fully understood as yet, e.g. Tanquana (Hartmann 1983: 37; Hartmann \& Liede 1986: 461). Those species that lack prominent closing bodies altogether often have other devices to achieve the occlusion of the locules, such as protrusions from the covering membranes in the form of ledges, sills, bulges or rodlets, by sterile funicles or by free ends of placentas. This seems to suggest that the occlusion of the locules is favoured by natural selection but is achieved by different means. Capsule types that have only very incomplete or no covering membranes are clearly less efficient with regard to their seed dispersal (e.g. Ihlenfeldt \& Struck 1987). These species also tend to be found in areas of higher rainfall (e.g. Delosperma), where it is not critical if seed is disseminated in one rainfall event if this is closely followed by more rain.

From an evolutionary point of view, certain adaptive pressures on dispersal mechanisms can influence the size and shape of the closing bodies, as they are obviously correlated with the dispersal syndrome. This was illustrated by Hartmann (1988: 329) in the example of Fenestraria - this species is dispersed as tumble fruits, and therefore only small closing bodies have evolved in its capsules.

\section{TAXONOMIC SIGNIFICANCE}

In view of our incomplete knowledge of the closing bodies of the Mesembryanthemaceae, it is premature to make firm proposals regarding the taxonomic significance of their structure. Owing to the variation observed in some genera and the only sporadic occurrence of these bodies, it is unlikely that extensive studies will eventually yield taxonomically significant features. While the structure of the closing bodies does not permit a new classification, some correlations to fruit types can be observed (Hartmann 1988: 327). Nevertheless, the structure and size of the closing bodies can mostly be used as diagnostic features of individual species and genera, and partly also of larger informal groups (Hartmann 1991, 1993).

\section{REFERENCES}

BERGER, A. 1908. Mesembrianthemen und Portulacaceen. Ulmer, Stuttgart.

BOLUS, H.M.L. 1927. South African succulents. South African Gardening \& Country Life 17: 399 .

BURGOYNE, P.M. 1998. Finding a place in the sun: where does Ruschia purpureostyla belong? Aloe 35,2: 60,61.

CHESSELET, P. \& HARTMANN, H.E.K. 1995. Khadia alticola Chess \& H.E.K. Hartm. spec. nov. (Mesembryanthema, Aizoaceae). Aloe 32: $46-49$.

CHESSELET, P., HARTMANN, H.E.K., HAHN, H., BURGOYNE, P \& SMITH, G.F. 1998. Taxonomic notes on the genus Khadia (Mesembryanthemaceae/Aizoaceae). Bothalia 28: 25-33.

CHINNOCK, R.J. 1996. To the limits of Disphyma (Aizoaceae: Ruschioideae) and beyond. Aloe 33: 59-61.

DEHN, M. 1988. Untersuchungen zum Merkmalsbestand und zur Stellung der Gattung Antimima N.E. Br. emend. Dehn (Mesembryanthemaceae Fenzl). Mitteilungen aus dem Institut für Allgemeine Botanik Hamburg 22: 189-215.

DEHN, M. 1992. Untersuchungen zum Verwandtschaftskreis der Ruschiinae (Mesembryanthemaceae Fenzl). Mitteilungen aus dem Institut für Allgemeine Botanik Hambung 24: 91-198.

GROEN, L.E. \& VAN DER MAESEN, L.J.G. 1999. Revision of the genus Faucaria (Ruschioideae: Aizoaceae) in South Africa. Bothalia 29: 35-58.

HAAS, R. 1976. Morphologische, anatomische und entwicklungsgeschichtliche Untersuchungen an Blüten und Früchten hochsukkulenter Mesembryanthemaceen-Gattungen. Dissertationes Botanicae: 33. Cramer, Vaduz.

HARTMANN, H.E.K. 1976. Monographie der Gattung Odontophorus N.E. Br. (Mesembryanthemaceae Fenzl) (Monographie der subtribus Leipoldtiinae Schw. I). Botanische Jahrbücher 97: $161-225$.

HARTMANN, H.E.K. 1977. Monographie der Gattung Argyroderma N.E. Br. (Mesembryanthemaceae Fenzl). Mitteilungen aus dem Institut für Allgemeine Botanik Hamburg 15: 121-235.

HARTMANN, H.E.K. 1978. Zur Kenntnis der Gattung Cephalophyllum N.E. Br. Botanische Jahrbücher 99: 264-302.

HARTMANN, H.E.K. 1982. Monographien der Subtribus Leipoldtiinae. III. Monographie der Gattung Fenestraria (Mesembryanthemaceae). Botanische Jahrbücher 103: 143-183.

HARTMANN, H.E.K. 1983. Untersuchungen zum Merkmalsbestand und zur Taxonomie der Subtribus Leipoldtiinae (Mesembryanthemaceae). Bibliographia Botanica 136: 1-67.

HARTMANN, H.E.K. 1984. Monographien der subtribus Leipoldtiinae VI. Monographie der Gattung Jondaaniella (Mesembryanthemaceae). Botanische Jahrbuicher 104:321-360. 
HARTMANN, H.E.K. 1988. Fruit types in Mesembryanthema. Beiträge zur Biologie der Pflanzen 63: 313-349.

HARTMANN, H.E.K. 1991. Mesembryanthema. Contributions from the Bolus Herbarium 13: 75-157.

HARTMANN, H.E.K. 1992. Ihlenfeldtia, a new genus in Mesembryanthema (Aizoaceae). Botanische Jahrbücher 114: 29-50.

HARTMANN, H.E.K. 1993. Aizoaceae. In K. Kubitzki, J.G. Rohwer \& V. Bittrich, The families and genera of vascular plants 2: 37-69. Springer Verlag, Berlin.

HARTMANN, H.E.K. 1996. Miscellaneous taxonomic notes on Aizoaceae. Bradleya 14: 29-56.

HARTMANN, H.E.K. 1998a. A letter to the MSG. Mesemb Study Group Bulletin 2: 32-34.

HARTMANN, H.E.K. 1998b. New combinations in Ruschioideae, based on studies in Ruschia (Aizoaceae). Bradleya 16: 44-91.

HARTMANN, H.E.K. 2001. Illustrated handbook of succulent plants. In 2 vols. Springer Verlag, Berlin.

HARTMANN, H.E.K. \& BRUCKMANN, C. 2000. The capsules of Drosanthemum Schwantes (Ruschioideae, Aizoaceae). Bradleya 18: 75-112.

HARTMANN, H.E.K. \& DEHN, M. 1987. Monographien der Subtribus Leipoldtiinae. VII. Monographie der Gattung Cheiridopsis (Mesembryanthemaceae). Botanische Jahrbücher 108: 567-663.

HARTMANN, H.E.K. \& DEHN, M. 1989. A re-examination of the genus Amphibolia (Mesembryanthemaceae). Bothalia 19: 179-182.

HARTMANN, H.E.K. \& GÖLLING, H. 1993. A monograph of the genus Glottiphyllum (Mesembryanthema, Aizoaceae). Bradleya 11: $1-49$.

HARTMANN, H.E.K. \& LIEDE, S. 1986. Die Gattung Pleiospilos s. lat. (Mesembryanthemaceae). Botanische Jahrbücher 106: 433-485.

HARTMANN, H.E.K. \& RUST, S. 1994. Monographie der Leipoldtiinae. IX. Monographie der Gattung Leipoldtia L.Bolus s. lat. (Aizoaceae). Verhandlungen des Naturwissenschaftlichen Vereins Hamburg NF 34: 275-351.

HERRE, H. 1971. The genera of the Mesembryanthemaceae. Tafelberg, Cape Town.

HUBER, J.A. 1924. Zur Morphologie von Mesembrianthemum. Botanisches Archiv 5: 7-25.

IHLENFELDT, H.-D. 1960. Entwicklungsgeschichtliche, morphologische und systematische Untersuchungen an Mesembryanthemaceen. Feddes Repertorium 63: 1-104.

IHLENFELDT, H.-D. 1971. Some aspects of the biology of dissemination of the Mesembryanthemaceae. In $\mathrm{H}$. Herre, The genera of the Mesembryanthemaceae: 28-34. Tafelberg, Cape Town.
IHLENFELDT, H.-D. \& STRUCK, M. 1987. Morphologie und Taxonomie der Dorotheanthinae Schwantes (Mesembryanthemaceae). Beiträge zur Biologie der Pflanzen 61: 411-453.

KLAK, C., BRUYNS, P.V. \& HEDDERSON, T. 2007. A phylogeny and new classification for Mesembryanthemoideae (Aizoaceae). Taxon 56: 737-756.

KLAK, C., KHUNOU, A., REEVES, G. \& HEDDERSON, T. 2003. A phylogenetic hypothesis for the Aizoaceae (Caryophyllales) based on four plastid DNA regions. American Journal of Botany 90,10: 1433-1445.

KURZWEIL, H. 2005. Observations on the development of the placentas and closing bodies in the fruit capsules of some Mesembryanthema (Aizoaceae). Botanische Jahrbücher 126: 385-401.

KURZWEIL, H. \& CHESSELET, P. 2003. Studies in the genus Machairophyllum (Mesembryanthemaceae), with notes on some related genera. Bothalia 33: 19-39.

LOCKYER, S. 1932. Seed dispersal from hygroscopic Mesembryanthemum fruits; Bergeranthus scapigerus Schw. and Dorotheanthus bellidiformis N.E. Br., with a note on Carpanthea pomeridiana N.E. Br. Annals of Botany 46: 323-342, plate X.

PAROLIN, P. 2001. Seed expulsion in fruits of Mesembryanthema (Aizoaceae): a mechanistic approach to study the effect of fruit morphological structures on seed dispersal. Flora 196: 313322.

PAROLIN, P. 2006. Ombrohydrochory: rain-operated seed dispersal in plants with special regard to jet-action dispersal in Aizoaceae. Flora 201: 511-518.

POPPENDIECK, H.H. 1976. Untersuchungen zur Morphologie und Taxonomie der Gattung Mitrophyllum Schwantes s.l. Botanische Jahrbücher 97: 339 -413.

SCHWANTES, G. 1952. Die Früchte der Mesembryanthemaceen. Vierteljahrsschrift der Naturforschenden Gesellschaft Zürich 97, Beiheft 2: 1-38.

SCHWANTES, G. 1957. Flowering stones and mid-day flowers. Ernest Benn, London.

SMITH, G.F., CHESSELET, P., VAN JAARSVELD, E.J., HARTMANN, H.E.K., HAMMER, S., VAN WYK, B.-E., BURGOYNE, P., KLAK, C. \& KURZWEIL, H. 1998. Mesembs of the world. Briza Publications, Pretoria.

STEINBRINCK, C. 1883. Über einige Fruchtgehäuse, die ihre Samen infolge von Benetzung freilegen. Berichte der Deutschen Botanischen Gesellschaft 1:339-347, 360 .

VOLK, O. 1960. Flowers and fruits of Mesembryanthemums. In H. Jacobsen, A handbook of succulent plants 3: 945-950. Blandford Press, London. 